\title{
Correction to: Emotion classification from speech signal based on empirical mode decomposition and non-linear features
}

\section{Speech emotion recognition}

\author{
Palani Thanaraj Krishnan ${ }^{1}$ · Alex Noel Joseph Raj $^{2}$ [D $\cdot$ Vijayarajan Rajangam $^{3}$
}

Published online: 22 May 2021

(c) The Author(s) 2021

\section{Correction to: Complex \& Intelligent Systems https://doi.org/10.1007/s40747-021-00295-z}

In the original article, the corresponding author name was published incorrectly. The correct name is Alex Noel Joseph Raj.

The original article has been corrected.

Open Access This article is licensed under a Creative Commons Attribution 4.0 International License, which permits use, sharing, adaptation, distribution and reproduction in any medium or format, as long as you give appropriate credit to the original author(s) and the source, provide a link to the Creative Commons licence, and indicate if changes were made. The images or other third party material in this article are included in the article's Creative Commons licence, unless indicated otherwise in a credit line to the material. If material is not included in the article's Creative Commons licence and your intended use is not permitted by statutory regulation or exceeds the permitted use, you will need to obtain permission directly from the copyright holder. To view a copy of this licence, visit http://creativecommons.org/licenses/by/4.0/.

The original article can be found online at https://doi.org/10.1007/ s40747-021-00295-z.

Alex Noel Joseph Raj

jalexnoel@stu.edu.cn

Palani Thanaraj Krishnan

palanithanaraj.k@gmail.com

Vijayarajan Rajangam

viraj2k@gmail.com

1 Department of Electronics and Instrumentation Engineering, St. Joseph's College of Engineering, Chennai, India

2 Department of Electronic Engineering, Shantou University, Shantou, China

3 Division of Healthcare Advancement, Innovation and Research, Vellore Institute of Technology, Chennai, India 